Katarzyna Szeler ${ }^{*}$

Włocławek

\title{
Wybrane metody terapii osób dotkniętych autyzmem w świetle literatury
}

\section{Wprowadzenie}

Celem artykułu jest przedstawienie wybranych metod terapii, jakie stosowane są w pracy z osobami autystycznymi. Pomimo wielu lat badań i poszukiwań nie udało się odnaleźć jednej skutecznej metody terapii. Obecnie istnieje ich bardzo wiele i, choć trudno jest jednoznacznie ocenić efekty każdej z nich, nie ulega wątpliwości, iż każda posiada swoją specyficzną wartość. Przedstawione poniżej metody terapii zostały wybrane z uwagi na ich popularność oraz stosunkowo bogatą i szczegółową dokumentację.

\section{Terapia w autyzmie}

Autyzm to całościowe, rozległe zaburzenie rozwoju, występuje częściej u chłopców niż u dziewczynek (w relacji 3:1) i ujawnia się u 15 na 10000 dzieci. Obecnie programy terapeutyczne dla poszczególnych dzieci mają charakter globalny - obejmują różne obszary rozwoju ${ }^{1}$.

Rozpoczęcie terapii w bardzo wczesnym okresie życia dziecka stanowi bazę dla późniejszych efektów. Im wcześniej dziecku uda się wiele osiagnąć, tym szybciej w przyszłości będzie mogło zacząć opanowywać złożone umiejętności. We wczesnym okresie rozwoju układ nerwowy charakteryzuje się

*Autorka jest absolwentką Uniwersytetu Mikołaja Kopernika w Toruniu, gdzie studiowała na kierunkach historia oraz pedagogika. Ukończyła również studia podyplomowe na Uniwersytecie Mikołaja Kopernika w Toruniu w zakresie logopedii.

Ukończone kursy to m.in.: „Terapia niedyrektywna dzieci autystycznych i dzieci z zaburzeniami zachowania” (Centrum Metodyczne Pomocy Psychologiczno-Pedagogicznej w Warszawie), „Metoda Dennisona” (Polskie Stowarzyszenie Kinezjologów w Warszawie).

${ }^{1}$ D. Danielewicz, E. Pisula, Terapia i edukacja osób z autyzmem, Warszawa 2003, s. 13. 
wyjątkowo dużą plastycznością, dzięki czemu istnieje możliwość skutecznej korekcji zaburzonych funkcji, a także kompensacji deficytów. Bardzo ważne jest, by uwzględniać preferencje dziecka, jego zainteresowania i ulubione formy aktywności. Wymaga to od terapeuty pewnego rodzaju otwartości i umiejętności podążania za dzieckiem. Szacunek dla niego i jego indywidualności to fundamentalna zasada terapii. Każdy program powinien posiadać wyraźną strukturę. Powinny być stosowane rozmaite metody, umożliwiające wszechstronne wspieranie rozwoju dziecka. Ważne jest, by prowadzenie terapii odbywało się w naturalnym środowisku, natomiast nacisk powinien być kładziony na rozwijanie zdolności komunikowania się, w tym także na pozawerbalne formy porozumiewania. Niezmiernie ważne jest, by włączać rodziców do pracy z dzieckiem, a następnie wspierać ich oraz rodzeństwo. Równie ważna jest integracja dziecka $\mathrm{z}$ rówieśnikami².

Metody terapeutyczne reprezentują dwa kierunki. Pierwszy kierunek to metody niedyrektywne, w których terapeuta powstrzymuje się od wpływania na poczynania pacjenta, od dawania mu rad i jakichkolwiek wskazówek. Drugi kierunek to metody dyrektywne, w których terapeuta kieruje pacjentem w celu wywołania w nim zgodnych z założeniami zmian. Jako pierwsze zostaną przedstawione metody oparte na założeniach terapii niedyrektywnej.

\section{Metody terapii niedyrektywnej}

Jak pisze H. Olechnowicz, niedyrektywność to przede wszystkim powstrzymywanie się od wydawania poleceń w sytuacji terapeutycznej i podczas zabawy. Celem tej terapii jest obniżanie lęku u osób z autyzmem oraz uczenie zachowań potrzebnych w środowisku. Droga ,wychodzenia z autyzmu” jest długim procesem, w którym porażki przeplatają się z sukcesami i który jest ogromnym wyzwaniem dla rodziców oraz terapeutów. Nagrodą za pełną poświęcenia pracę z dzieckiem autystycznym jest przełamanie jego izolacji społecznej i poprawa jego funkcjonowania w otoczeniu.

Do grupy terapii niedyrektywnych można zaliczyć Terapię Zabawową opracowaną przez Virginię Axline. Zadaniem terapeuty jest stwarzanie odpowiedniego klimatu, optymalnego dla rozwoju dziecka. V. Axline uważała, że człowiek posiada od początku swego istnienia, indywidualne możliwości rozwojowe oraz silną tendencję zmierzającą do realizowania tych możliwości i zdolności. Jest to tzw. tendencja do samoaktualizacji. Jeżeli pozwolimy jednostce działać zgodnie z tendencją do samoaktualizacji, to będzie się ona rozwijać w kierunku społecznie pożądanym, coraz pełniej wykorzystując swoje możliwości ${ }^{3}$.

${ }^{2}$ E. Pisula, Małe dziecko z autyzmem, Gdańsk 2003, s. 113-127.

${ }^{3}$ B. Borsuk, Niedyrektywna terapia zabawowa. Koncepcja V. M. Axline, Psychologia Wychowawcza 1979, nr 5, s. 674-675. 
Do prowadzenia terapii nie muszą być przygotowane specjalne pomieszczenia, wiele sesji prowadzonych przez V. Axline odbywało się na przykład w klasie szkolnej. Wszystkie zgromadzone w pokoju zabawki muszą być proste w konstrukcji, by nie stwarzały dziecku dodatkowych trudności w trakcie operowania nimi. Muszą być mocne i wytrzymałe. Postacie lalek powinny reprezentować wszystkich członków rodziny: matkę, ojca, dziadków, starsze i młodsze rodzeństwo. W pokoju zabawowym powinna również znajdować się skrzynia z piaskiem ${ }^{4}$.

Virginia Axline sformułowała osiem zasad, które terapeuta powinien respektować i które to zasady powinny być realizowane w toku niedyrektywnej terapii zabawą.

Zasada 1. Ustanowienie porozumienia - Terapeuta musi wytworzyć ciepły, przyjacielski stosunek z dzieckiem, co ułatwi mu szybsze porozumienie $\mathrm{z}$ nim.

Zasada 2. Całkowite akceptowanie dziecka.

Zasada 3. Wytwarzanie atmosfery swobody - Terapeuta wytwarza atmosferę swobody, żeby dziecko czuło, iż może wyrazić swoje uczucia bez skrępowania.

Zasada 4. Rozpoznawanie i odzwierciedlanie uczuć - Terapeuta uważnie rozpoznaje uczucia, które dziecko wyraża, i odzwierciedla je w taki sposób, aby dziecko zrozumiało (uświadomiło sobie) swoje zachowanie.

Zasada 5. Szanowanie dziecka - Terapeuta szanuje zdolność dziecka do rozwiązywania jego własnych problemów (Dziecko ponosi odpowiedzialność za dokonywane wybory i zmiany w zakresie swego zachowania).

Zasada 6. Dziecko kieruje - Terapeuta nie kieruje czynnościami dziecka ani rozmową z nim.

Zasada 7. Terapia nie może być przyśpieszana.

Zasada 8. Wartość ograniczeń ${ }^{5}$.

W terapii niedyrektywnej ograniczeń jest mało, ale te, które istnieją, są ważne. Dziecku nie wolno niczego umyślnie niszczyć, nie wolno też atakować terapeuty, jak i innych dzieci. Terapeucie natomiast nie wolno narażać dziecka na niebezpieczeństwo.

Następną metodą z grupy terapii niedyrektywnych jest Muzykoterapia. Przed rozpoczęciem pracy z dzieckiem należy dokonać wstępnej diagnozy określającej wskazania i przeciwwskazania do stosowania muzykoterapii, jej cele i zadania, rodzaj (indywidualna lub grupowa), środki oddziaływania, okres stosowania oraz szczegółowy program do realizacji. W swym działaniu terapeuta stara się u pacjenta znaleźć nie tylko zaburzenia, opóźnienia, trudności, ale także jego

\footnotetext{
${ }^{4}$ Tamże, s. 676-677.

${ }^{5}$ Tamże, s. 678-682.
} 
mocne strony: umiejętności, zdolności, zainteresowania, na bazie których będzie mógł prowadzić działania usprawaniająco-korekcyjne ${ }^{6}$.

Każdy utwór muzyczny, oprócz zawartej w nim treści emocjonalnej, jest dziełem niezwykle dokładnie uporządkowanym według pewnych reguł kompozytorskich. Być może właśnie to „królestwo porządku”, gdzie każdy dźwięk, każdy wyraz muzyczny i zdanie ma swoje miejsce, tak fascynuje i przyciaga uwagę dziecka autystycznego ${ }^{7}$. Dźwięki w różnych swoich kombinacjach pozwalają dziecku autystycznemu nie tylko na przekazanie swoich uczuć, stanów wewnętrznych, pragnień, lecz jednocześnie dają mu wiele satysfakcji z wykonywanych manipulacji dźwiękowych, ponieważ dźwięk dość często jest przedmiotem wykorzystanym w stereotypiach sensorycznych. Również wiele osób pracujących z osobami autystycznymi zauważa szczególne zainteresowanie tych osób rytmem ${ }^{8}$.

Bardzo ważnym elementem terapii jest dobrze dobrany repertuar muzyczny, ponieważ muzyka sama w sobie może stać się dla osoby autystycznej obsesja, mogącą wywołać lub wzmocnić proces cofnięcia się i samoizolacji. W muzykoterapii autyzmu niezmiernie ważne jest przestrzeganie poniższych zasad:

Indywidualizacji: każde dziecko powinno mieć opracowany oddzielny program terapeutyczny;

Kontroli i strukturalizacji całego procesu terapii muzyka. Terapeuta na podstawie diagnozy winien wyszczególnić przebieg każdej konkretnej części terapii. Powinien być gotów na szybkie reagowanie i natychmiastowe zmiany w terapii dziecka;

Uzgodnienia programu muzykoterapeutycznego z innymi programami terapeutycznymi, ponieważ do każdego dziecka podejście musi być indywidualne. Każde dziecko, nawet w małej grupie, będzie się różnić czy to na poziomie zdolności wysepkowych ${ }^{9}$, preferencji, różnic kulturowych czy poziomu intelektualnego i emocjonalnego ${ }^{10}$.

${ }^{6}$ P. Cylulko, Rola muzykoterapii w procesie usprawniania niepetnosprawnych pacjentów, Muzykoterapia Polska 2003, nr 1 (5), s. 15-25.

${ }^{7}$ E. Jutrzyna, Dziecko autystyczne w kręgu muzyki, w: J. Błeszyński (red.), Wspomaganie rozwoju osób z autyzmem, Kraków 2004, s. 40.

${ }^{8}$ Tamże, s. 41.

${ }^{9}$ Wśród osób autystycznych o umiarkowanym lub lekkim stopniu upośledzenia umysłowego oraz o inteligencji mieszczącej się w normie spotkać można jednostki ze szczególnymi zdolnościami, z uwagi na swój charakter określanymi jako wysepkowe. Są to m.in. zdolności: muzyczne - np. wybitnie dobry słuch muzyczny, pamięć muzyczna, komponowanie melodii; językowe - np. opanowanie kilku języków obcych przez dziecko uczące się ich samodzielnie, często w sposób niezauważalny dla otoczenia; pamięciowe - dotyczą najczęściej pamięci mechanicznej, np. zapamiętanie treści książki telefonicznej, rozkładu jazdy pociągów, haseł z encyklopedii; percepcyjne - np. bardzo szybkie i sprawne układanie puzzli, składających się z kilkuset czy kilku tysięcy elementów; arytmetyczne - błyskawiczne wykonywanie w pamięci skomplikowanych działań arytmetycznych, np. mnożenie dwóch wielocyfrowych liczb, wyciaganie pierwiastka z kilkucyfrowej liczby, przy czym osoba ta nie jest w stanie dokonać analizy tej operacji; plastyczne - wybitne zdolności rysunkowe.

${ }^{10}$ Tamże, s. 45. 
Muzykoterapia pozwala na stworzenie dziecku autystycznemu warunków do samorealizacji, umożliwiających zmniejszenie napięć psychofizycznych, dających odprężenie, radość, wyzwolenie i rozładowanie zablokowanych energii. Zajęcia terapeutyczne uczą czerpania satysfakcji ze współdziałania w grupie: pomagają w rozwijaniu postaw niezależnych, kształtują świadomość.

Autorami kolejnej metody są Barry i Neil Kaufman. Na podstawie zebranych przez nich doświadczeń został napisany program, który znany jest pod nazwą: Metoda Opcji.

Do głównych założeń terapii zaliczono:

1) postawę akceptacji i aprobaty,

2) stałe motywowanie małego pacjenta,

3) rozwijanie zindywidualizowanego programu terapeutycznego ${ }^{11}$.

Metoda Opcji jest bardzo prosta w przekazie i bardzo trudna do zrealizowania. Nie jest to tylko sposób oddziaływania terapeutycznego, ale także (czy też przede wszystkim) - cała postawa życiowa, stosunek do świata i innych ludzi oparty na stwierdzeniu, że kochać kogoś, to pozwolić mu być takim, jakim jest i odnaleźć w przebywaniu z nim swoje szczęście ${ }^{12}$.

Punktem wyjścia do pracy Metodą Opcji jest zrozumienie niemożności dziecka do komunikowania się. W ślad za zrozumieniem dziecka idzie świadomość, że poprzez swoje chaotyczne, bezładne ruchy nadaje nam ono różne komunikaty o tym, że się boi, że czuje się mało bezpiecznie, że nie potrafi sobie poradzić z sygnałami, które ciagle do niego docierają. Rodzice, rozumiejąc swoje dziecko, zniżają się do jego poziomu, próbują z nim razem na tym poziomie znaleźć porozumienie. Stosując Metodę Odzwierciedlania, przekazują dziecku informacje o swojej akceptacji, o tym, że są do niego podobni. Metoda ta sprowadza się do dokładnego naśladowania zachowań dziecka. Klaśnięciem odpowiadamy na klaśnięcie, krzykiem na krzyk. W ten sposób pomagamy dziecku zauważyć nas i rozpoznać jako niezagrażający element jego świata ${ }^{13}$.

Inną formą terapii jest Metoda Dobrego Startu (MDS). Jej pierwowzorem była metoda Le Bon Dèpart opracowana we Francji przez Theę Bugnet. Metoda Dobrego Startu to polska modyfikacja tejże metody, którą opracowała Marta Bogdanowicz. W porównaniu z oryginałem wprowadzono nowe elementy: formę i układ ćwiczeń, nowe zestawy wzorów z polskimi piosenkami ludowymi i dziecięcymi ${ }^{14}$.

Metoda Dobrego Startu ma dwojakie zastosowanie: w rehabilitacji i profilaktyce. Może być stosowana w pracy zarówno z dziećmi o prawidłowym rozwoju

${ }^{11}$ J. J. Błeszyński, Terapia dziecka autystycznego i z głębokimi deficytami rozwojowymi, Forum Pedagogów Specjalnych XXI wieku, t. III, red. J. Pańczyk, Łódź 2002, s. 22.

${ }^{12}$ M. Multan, Nie tylko profesjonaliści moga być terapeutami, Dziecko Autystyczne 2001, t. IX, nr 1, s. 90.

${ }^{13}$ J. Kruk-Lasocka, Autyzm czy nie autyzm? Problemy diagnozy i terapii pedagogicznej mabych dzieci, Wrocław 1999, s. 77.

${ }^{14}$ A. Frączek, Metoda Dobrego Startu jako jedna z form terapii dzieci z autyzmem, Dziecko Autystyczne 2001, t. IX, nr 2, s. 40. 
psychomotorycznym i aktywizować ten rozwój, jak i z dziećmi, których rozwój jest zaburzony - usprawniając nieprawidłowo rozwijające się funkcje.

Program realizowany przy zastosowaniu tej metody obejmuje:

1. Zajęcia wprowadzające - celem tych zajęć, jak sama nazwa sugeruje, jest przygotowanie dzieci do ćwiczeń właściwych. Są to ćwiczenia dyscyplinujące i koncentrujące uwagę.

2. Zajęcia właściwe - w skład których wchodzą ćwiczenia ruchowe, będące pierwszym ich etapem, usprawniające analizator kinestetyczno-ruchowy ${ }^{15}$. Ćwiczenia ruchowo-słuchowe kształcą gnozję ${ }^{16}$ palców, precyzję i elastyczność ruchów, koordynację ruchów obu rąk, angażują analizator kinestetyczno-ruchowy i słuchowy. Kolejne stosowane ćwiczenia - ruchowo-słuchowo-wzrokowe, kształcą analizator kinestetyczno-ruchowy, słuchowy i wzrokowy ${ }^{17}$.

3. Zajęcia końcowe mają charakter ćwiczeń wokalno-rytmicznych. Zabawowa forma usprawnia jednocześnie motorykę i percepcję słuchową ${ }^{18}$.

Podstawowym warunkiem podjęcia pracy tą metodą z dzieckiem autystycznym jest osiagnięcie przez nie takiego poziomu funkcjonowania emocjonalnospołecznego, który umożliwi mu nawiązanie kontaktu choćby z jedną osobą. Następnie ważny jest właściwy wybór grupy. Grupa musi być mała, ponieważ konieczna jest obecność dorosłych podczas zajęć. Należy znacznie zindywidualizować program ćwiczeń pod kątem potrzeb, możliwości i ograniczeń danego dziecka, kładąc nacisk na budowanie świadomości własnego ciała, poczucie tożsamości i kontaktów z jednym partnerem, a następnie z grupa ${ }^{19}$.

W pracy z dzieckiem autystycznym wykorzystuje się również Developmental Movement (Ruch Rozwijający). Jako metoda został on opracowany przez Weronikę Sherborne $^{20}$. W Polsce metoda znana również pod nazwą: Metoda Weroniki Sherborne.

Do podstawowych zadań tej metody zaliczyć należy: kształtowanie poczucia tożsamości, rozwój obrazu siebie, rozwój umiejętności nawiązywania kontaktu, kształtowanie autoorientacji i orientacji przestrzennej, usprawnianie ruchowe w zakresie możliwym do osiagnięcia przez dziecko, kształtowanie koordynacji wzrokowo-ruchowej, dostarczanie radosnych przeżyć związanych z aktywnością ruchową dziecka, rozwijanie pewności siebie i odwagi ${ }^{21}$.

${ }^{15}$ A. Frączek, Metoda Dobrego Startu jako jedna z form terapii dzieci z autyzmem, Dziecko Autystyczne 2001, t. IX, nr 2, s. 41.

${ }^{16}$ Zdolność do rozpoznawania na przykład: kształtów, wielkości, temperatury danych przedmiotów. U osób niewidomych tzw. „,widzenie ręczne”.

${ }^{17}$ Tamże, s. 42.

${ }^{18}$ Tamże, s. 43.

${ }^{19}$ M. Bogdanowicz, Dostosowanie metody dobrego startu do potrzeb dzieci autystycznych - efektywność tej metody, w: Autyzm kontrowersje i wyzwania, red. W. Dykcik, Poznań 1994, s. $155-156$.

${ }^{20}$ M. Bogdanowicz, B. Kisiel, M. Przasnyska, Metoda Weroniki Sherborne w terapii $i$ wspomaganiu rozwoju dziecka, Warszawa 1992, s. 7-8.

${ }^{21}$ Z. Szot, Aktywność ruchowa w terapii dzieci autystycznych, Gdańsk 1997, s. 29. 
Autorka tejże metody wyróżnia następujące grupy ćwiczeń, wspomagające rozwój dziecka:

I - ćwiczenia prowadzące do poznania własnego ciała (np. czołganie, wykonywanie różnorodnych ruchów podczas leżenia, siedzenia);

II - ćwiczenia pomagające zdobyć pewność siebie i poczucie bezpieczeństwa w kontakcie (np. „tunel” - dziecko przechodzi pod tunelem, który tworzą inne osoby);

III - ćwiczenia ułatwiające nawiązywanie kontaktu i współpracy z partnerem i grupa:

- ćwiczenia „Z” w parach (przeciaganie, kołysanie się z partnerem w różnorodny sposób);

- ćwiczenia „przeciwko” (np. „paczka” - dziecko zwija się w kłębek, a współćwiczący stara się rozwiązać paczkę);

- ćwiczenia „razem” (obaj partnerzy są aktywni);

IV - ćwiczenia twórcze - rozwijanie aspektów ruchu proponowanych przez członków grupy 22 .

Zajęcia terapeutyczne tą metodą powodują obniżenie lęku u dzieci, wpływają na rozwój społeczny, intensyfikują pozytywne reakcje na bliski kontakt z partnerem. Ponadto polepsza się koncentracja uwagi oraz znajomość orientacji i własnego ciała. Wzrasta aktywność ruchowa dzieci²3.

Kolejną metodą z grupy terapii niedyrektywnych jest Program Aktywności Marianny i Christophera Knillów.

Już w okresie prenatalnym jesteśmy uwrażliwiani na bodźce dotykowe. Praca z ciałem, wykorzystywanym jako pierwotny kanał komunikacyjny, przez który możliwe jest nawiązanie kontaktu interpersonalnego i stworzenie więzi emocjonalnych $\mathrm{z}$ drugą osobą, stanowi fundament tej terapii ${ }^{24}$. Podstawowym założeniem tego programu jest oparcie działań stymulujących rozwój dziecka na zmyśle dotyku. Doświadczenie kontaktu fizycznego jest podstawą rozwoju związków z innymi ludźmi i komunikacji między nimi.

Metoda Knillów powstała jako odpowiedź na trudności w komunikacji z osobami niepełnosprawnymi. Składa się z dwóch głównych części: „Dotyk i Komunikacja” oraz „Program Aktywności - Świadomość Ciała, Kontakt i Komunikacja". Są to programy aktywności przeznaczone do indywidualnej pracy z dzieckiem, wzbogacone kasetami ze specjalnie skomponowaną muzyką, która towarzyszy wszystkim czynnościom.

${ }^{22}$ E. Jaworska, T. Gałkowski, D. Kocyłowska, Rozwój ruchowy i dojrzałość społeczna dziecka z autyzmem, Dziecko Autystyczne 2001, t. IX, nr 2, s. 11-12.

${ }^{23}$ M. Sekułowicz, Wybrane metody usprawniania dzieci z autyzmem, w: D. Danielewicz, E. Pisula, dz. cyt., s. 91-92.

${ }^{24}$ G. Stano, Zastosowanie metody Knilla $w$ indywidualnym nauczaniu dziecka autystycznego, w: Autyzm: wyzwanie naszych czasów, red. T. Gałkowskiego, J. Kossewskiej, Kraków 2000, s. 148. 
Pierwsza część - Dotyk i Komunikacja - ma na celu wykształcenie świadomości własnego ciała, nauczenie odbierania bodźców zmysłowych z otoczenia. W sytuacji, gdy praca dotyczy dzieci autystycznych, wskazane jest, aby wcześniej dowiedzieć się o preferencjach dotykowych dziecka. Może się bowiem okazać, iż dziecko nie lubi delikatnego dotyku, ale mocny ucisk. Metoda powinna być stosowana w jasno określonym cyklu zajęć, systematycznie, lecz niezbyt często, 2-3 razy w tygodniu, aby dla dziecka nie stało się monotonne słuchanie tej samej muzyki. Ważna jest także pora dnia, w której prowadzone są zajęcia.

Etap „Dotyk i Komunikacja” powinien trwać do momentu, gdy dziecko zacznie nawiązywać kontakt z terapeutą oraz pojawią się pierwsze oznaki rozumienia przez nie własnego ciała. Wymaga to od terapeuty dzieci autystycznych dużej wiedzy i umiejętności obserwacji. „Program Aktywności” powinien być realizowany jako kontynuacja poznawania własnego ciała i komunikowania się $\mathrm{z}$ otoczeniem.

W pracy z dziećmi autystycznymi niejednokrotnie niezbędna staje się obecność co najmniej dwóch osób: matki, siedzącej za plecami dziecka i przytulającej je do siebie, oraz siedzącego naprzeciwko niej terapeuty, którego zadaniem jest określonych ćwiczeń w trakcie zajęć. Stosując Programy Aktywności, rozwijamy u dziecka kontakt społeczny, naśladownictwo, ruch i znajomość własnego ciała $^{25}$.

Do innych ciekawych form pracy z dzieckiem autystycznym należy Metoda Integracji Sensorycznej (SI), zaproponowana po raz pierwszy przez S. Jean Ayres. Termin integracja sensoryczna precyzyjnie określa procesy percepcji zmysłowej wrażeń docierających do naszego ciała i integrowanych w układzie nerwowym, tak by mogły być użyte do odpowiednich reakcji ${ }^{26}$.

Wspomniana S. Jean Ayres definiowała integrację sensoryczną jako proces, dzięki któremu nasz mózg, otrzymując informacje ze wszystkich zmysłów, dokonuje ich rozpoznania, segregowania i interpretacji, a także integruje je ze sobą oraz z wcześniejszymi doświadczeniami i na tej podstawie tworzy odpowiednią do sytuacji reakcję (zwaną w teorii SI reakcją adaptacyjną). Inaczej mówiąc, jest to taka organizacja wszystkich wrażeń, by mogły być przez człowieka wykorzystane do celowego, zakończonego sukcesem działania.

Terapia w Metodzie SI wygląda jak zabawa, ale jest to zabawa „naukowa”, poprzez którą układ nerwowy i mózg uczą się i integrują wrażenia zmysłowe, nabywają doświadczenia w ich celowym wykorzystaniu. Wśród używanego sprzętu są różnego typu huśtawki, hamaki, platformy równoważne, duże piłki i wałki, deskorolki, talerze obrotowe itp. W czasie terapii dziecko ma nie tyle nauczyć się konkretnych umiejętności, ile raczej usprawnić bazowe systemy sensoryczne

${ }^{25}$ L. Gąsecka, Działalność terapeutyczna i wspierajaca rozwój dzieci z autyzmem, Dziecko Autystyczne 2001, t. IX, nr 1, s. 125.

${ }^{26}$ V. F. Maas, Uczenie się przez zmysty. Wprowadzenie do teorii Integracji Sensorycznej, Warszawa 1998, s. 15-18. 
i procesy nerwowe, leżące u podłoża tych umiejętności, więc umiejętności te pojawią się jako naturalna konsekwencja terapiii ${ }^{27}$.

Celem tej terapii jest dostarczenie dziecku doświadczeń poprzez odpowiednio dobraną sekwencję ćwiczeń sensoryczno-motorycznych. Program usprawnia odbiór i integrację bodźców sensorycznych w ośrodkowym układzie nerwowym. Wzrasta poczucie bezpieczeństwa dziecka, świadomość własnych odczuć i emocji.

Znaną formą pracy z dziećmi autystycznymi jest również Metoda Felice Affolter, którą H. Olechnowicz określiła jako „psychopedagogikę rozumnego działania dłoni”.

Tekst książki F. Affolter zawiera wiele przykładów, starannie wybranych z obfitego i różnorodnego materiału. Są one szczególnie ważne dla zrozumienia początków rozwoju i jego zaburzeń, a także dla opisu procesu uczenia się. Dają też one wyobrażenie o znaczeniu, jakie ma obserwacja ${ }^{28}$.

Autorka tej metody skupia się przede wszystkim na rozwiązywaniu przez dziecko problemów dnia codziennego, a więc przede wszystkim na wyzwalaniu celowego i skutecznego działania dłoni i poznawania własnego działania. Pomoc pacjentowi polega na tym, że instruktor kładzie swoje ręce na zewnątrz dłoni pacjenta i lekko ukierunkowuje ich działanie, wyczuwając, czy i kiedy pacjent jest gotowy do przyzwolenia, by poddać się kierowaniu. Instruktor nigdy nie wyręcza pacjenta, sedno metody polega właśnie na tym, że pacjent przeżywa wysiłek jako własny, doznaje siebie jako sprawcę $e^{29}$.

Dzieci autystyczne cierpią na nadwrażliwość wszystkich receptorów. Reagują niekiedy panicznie na silne dźwięki, ostre światło, dotyk skóry. Także ich dłonie są nadwrażliwe. Dzieci te uciekają od dotykania czegokolwiek, wolą posłużyć się w charakterystyczny dla nich sposób ręką dorosłego. Praca metodą F. Affolter pozwala na stopniowe przezwyciężanie lęku przed dotykaniem i stopniowe hartowanie wnętrza dłoni ${ }^{30}$.

Działania, jakich uczy F. Affolter w toku swojej terapii, to rozwiązywanie problemów życia codziennego, których sensowność pacjent rozumie. Nie używa się zabawek. Dużo miejsca zajmuje kontakt dłoni z materią żywą, plastyczną, jak owoce, jarzyny. Tworzywa te silnie oddziałują na zmysły i emocje. Budzą bogate skojarzenia, mają swój własny kształt, kolor, ciężar, zapach, smak, temperaturę, wilgotność.

Terapeuta powinien zawsze pamiętać, że celem jego pracy nie jest samo usprawnienie dłoni, lecz poprzez działanie dłoni umożliwienie pacjentowi myśle-

${ }^{27}$ M. Sekułowicz, dz. cyt., s. 76.

${ }^{28}$ F. Affolter, Spostrzeganie, rzeczywistość, język, Warszawa 1997, s. 12.

${ }^{29}$ B. Sidor, Rola świadomości ciała w procesie terapii dziecka upośledzonego umystowo, Forum..., s. 265.

${ }^{30}$ H. Olechnowicz, Przez ręce do głowy $i$ serca. Kształtowanie rozumnego działania dłoni. Metoda Felicji Affolter. Perspektywy zastosowania w terapii dzieci autystycznych, Szkoła Specjalna 1997, t. LVII, nr 4 (192), s. 217. 
nia o własnym działaniu, a w efekcie końcowym - integracja działania z językiem, mową. Praca rękami pacjenta sprawia, że po pewnym czasie następuje koordynacja wzroku i działania ręki, a więc osiagnięty jest podstawowy cel terapii: integracja dotyku z doznaniami innego zmysłu ${ }^{31}$. Metoda F. Affolter pomaga również w rozwijaniu znajomości schematu ciała i praksji, a także - dzięki zastosowaniu jej w praktycznych działaniach dnia codziennego - zwiększa samodzielnośćc ${ }^{32}$.

W pracy z dziećmi autystycznymi wykorzystuje się również Paluszkowe zabawy. Wiadomo, że sprawność manualna to doskonalenie się struktur ruchowych w mózgu. Struktury te odpowiedzialne są także za ruchowy aspekt mowy. Rosnąca precyzja małych ruchów jest również ściśle związana z kontrolującą rolą wzroku. Daje początek praksji, co z kolei wpływa na tworzenie schematu ciała, obrazu siebie i obrazu świata. Jednocześnie ćwiczenia rozwijające sprawność palców mogą być doskonałym pretekstem do wyciszenia, doskonalenia stanu koncentracji, spostrzegawczości czy pamięci ${ }^{33}$.

Zabawy paluszkowe są to drobne formy zabawowe, w których osoba dorosła wypowiada krótki tekst bądź opowiada krótką historyjkę, obrazując go za pomocą dłoni i palców swoich lub dziecka. Zabawy te dają dzieciom poczucie bezpieczeństwa poprzez swoją powtarzalność i możliwość przewidzenia następnego ruchu podczas opowiadania znanej im już historyjki.

Zabawy paluszkowe podtrzymują i wzmacniają aktywność małego dziecka, które spontanicznie podejmuje zabawę swoimi rączkami i paluszkami. Poprawiają sprawność manualna, która potrzebna jest przy wykonywaniu czynności wymagających precyzyjnych ruchów ręki (np. przy pisaniu lub malowaniu). Dziecko podczas zabaw uczy się naprzemienności, co jest podstawą dialogu. W trakcie zabawy dziecko wzbogaca swoje słownictwo. To wszystko wpływa korzystnie na rozwój jego mowy. Do najbardziej znanych zabaw należą: „Sroczka”, „Kominiarz”, „Rak”"34. Zabawy paluszkowe w niniejszym artykule zamykają opisywaną grupę terapii niedyrektywnych.

\section{Metody terapii dyrektywnej}

Druga grupa metod, stosowanych w pracy z osobami z autyzmem, to metody terapii dyrektywnej. Głównym założeniem terapii dyrektywnych jest kształtowanie zachowań adaptacyjnych lub redukcja zachowań niepożądanych. Sposób prowadzenia terapii opiera się na behawioralnym przekonaniu, że w dowolny sposób można kształtować zachowanie poprzez odpowiednie manipulowanie. Celem tej terapii jest nauczenie dziecka przede wszystkim zachowań adaptacyj-

\footnotetext{
${ }^{31}$ Tamże, s. 218.

${ }^{32}$ M. Sekułowicz, dz. cyt., s. 92.

${ }^{33}$ J. Kruk-Lasocka, dz. cyt., s. 85.

${ }^{34}$ W. Szumanówna, Zabawy z najmłodszymi dziećmi, Warszawa 1997, s. 8.
} 
nych, które potrzebne są, by dziecko osiagnęło jak najwyższy stopień samodzielności i adaptacji w środowisku. Ważnym celem tej terapii jest generalizowanie i utrzymywanie efektów w czasie, a także angażowanie sytuacji uczenia się w sytuacji codziennej aktywności dziecka.

Interesujący projekt pracy z osobami autystycznymi został opracowany przez E. Schoplera i jego współpracowników w Północnej Karolinie (USA). Program TEACCH (Treatment and Education of Autistic and Related Com-munication Handicapped Children), czyli program Terapii i Edukacji Dzieci Autystycznych oraz Dzieci z Zaburzeniami w Komunikacji, obejmuje większość aspektów pomocy rodzinom, w których żyje dziecko autystyczne ${ }^{35}$.

Program ten polega na skupieniu się na osobie $z$ autyzmem i opracowaniu dla niej programu uwzględniającego jej umiejętności, zainteresowania i potrzeby. Do najważniejszych elementów tej metody należą: koncentracja na danej osobie, szeroko pojęta strategia bazująca na jej dotychczasowych umiejętnościach i zainteresowaniach, przyjęcie odpowiednich zmian i zrozumienie istoty autyzmu ${ }^{36}$.

Terapia obejmuje opracowywane indywidualnie programy interwencyjne, jak również konsultacje prowadzone w szkole oraz innej instytucji. Takie podejście obejmuje także rodziców - albo przez zachęcanie ich do udziału w szkoleniach i korzystania z poradnictwa, albo pomoc w tworzeniu grup wsparcia dla rodziców. Program TEACCH łączy również terapię z metodami diagnozowania i oceniania ${ }^{37}$.

Koncepcje i zasady terapeutyczne, leżące u podstaw TEACCH, to przede wszystkim: polepszenie możliwości adaptacyjnych, rodzice jako współterapeuci, ustalenie programu indywidualnej terapii, struktury nauczania, zastosowanie terapii behawioralnej i percepcyjnej, uniwersalny model szkolenia, podnoszenie umiejętności is.

Podstawą do opracowania indywidualnego programu terapii są takie narzędzia jak CARS, PEP-R czy AAPEP. Model TEACCH zakłada, że istnieją ogólne strategie i techniki przydatne w pracy z osobami autystycznymi, ale konkretne sposoby postępowania są różne w poszczególnych przypadkach ${ }^{39}$.

Oddział TEACCH pełni rolę międzynarodowego modelu dostarczającego wzorcowych usług dla osób z autyzmem i ich rodzin w całej Północnej Karolinie. Za pośrednictwem swoich dziewięciu ośrodków regionalnych TEACCH oferuje ocenę diagnostyczną, opracowywanie zindywidualizowanych programów nauczania, szkolenia z zakresu rozwijania umiejętności funkcjonowania społecznego, szkolenia zawodowe oraz poradnictwo i szkolenia dla rodzicó ${ }^{40}$.

${ }^{35}$ G. B. Mesibov, Czym jest TEACCH?, Autyzm 2004, nr 3, s. 14.

${ }^{36}$ Tamże, s. 12.

${ }^{37}$ S. Baron-Cohen, P. Bolton, Autyzm fakty, Kraków 1999, s. 75.

${ }^{38}$ L. Bobkowicz-Lewartowaska, Autyzm dziecięcy zagadnienia diagnozy i terapii, Kraków 2005, s. 118 .

${ }^{39}$ Tamże, s. 119.

${ }^{40}$ G. B. Mesibov, dz. cyt., s. 14-15. 
Inną formą pracy z osobami autystycznymi jest Metoda Stymulowanych Seryjnych Powtórzeń (SSP) autorstwa Z. Szota. Pierwsze próby pracy tą metodą podjęto w Ośrodku Pomocy Terapeutycznej dla Osób Autystycznych w Gdańsku w 1991 roku. Terapia ruchowa dzieci autystycznych oparta została o metody i założenia usprawniania dzieci zdrowych. Głównym celem stymulacji jest zwiększenie liczby bodźców atakujących korę mózgową, w której odbywa się proces przetwarzania informacji, uzewnętrzniający się $\mathrm{w}$ akcie ruchowym, bo jeśli na receptory nie działają żadne bodźce ani bodźce podprogowe, to określone reakcje nie mogą się również rozwinąć. Jedną z wielu zalet tej terapii jest to, iż każdą ze stron ciała można pobudzić osobno ${ }^{41}$. Dzięki tej terapii następuje odreagowanie napięć, zmniejsza się liczba zachowań destrukcyjnych i autostymulacyjnych. Również podczas terapii następuje zwiększenie samej wydolności fizycznej dziecka, która jest potrzebna do jego prawidłowego rozwoju.

Zadaniem metody Stymulowanych Seryjnych Powtórzeń Ćwiczeń jest zwiększenie dopływu liczby naturalnych bodźców do kory mózgowej, by w ten sposób przyśpieszać proces analizy i przetwarzania, co następnie powinno uzewnętrznić się w szybszym opanowaniu umiejętności ruchowych i zmianach osobowościowych ${ }^{42}$.

Jak opisuje Z. Szot w opublikowanych badaniach, w początkowym okresie stosowano 2-3 serie ćwiczeń z przerwami pomiędzy nimi trwającymi pół do półtorej minuty. Najmniejsza liczba ćwiczeń wynosiła pięć powtórzeń w jednej serii. $\mathrm{W}$ trakcie nabywania umiejętności wzrastała liczba ćwiczeń w jednej serii nawet do trzydziestu powtórzeń.

Programy ruchowe, których podstawą były ćwiczenia gimnastyczne, zostały podzielone według następujących kryteriów:

- kryterium czynności mięśni ze względu na wykonywaną pracę,

- kryterium doboru ćwiczeń ze względu na spełnianą funkcję.

Zastosowanie metody Stymulowanych Seryjnych Powtórzeń Ćwiczeń wykazało wyraźnie wpływ ruchu na sposób zachowania się dziecka autystycznego w jego funkcji ruchowej. W terapii należy zachować obowiązkowo prosty schemat: praca - odpoczynek - praca - odpoczynek. Istotne jest określenie właściwych dziennych proporcji pomiędzy pracą a odpoczynkiem. Stosowanie tej metody przyczynia się przede wszystkim do rozwoju motoryki dużej, na której bazuje rozwój motoryki małej. Poczynione przez autora w toku badań obserwacje tej metody potwierdziły związek pomiędzy liczbą powtórzeń ćwiczeń a zmianami zachodzącymi w motoryce ${ }^{43}$.

Ciekawą formą pracy z dzieckiem autystycznym jest również metoda wymuszonego kontaktu. Terapia holding wywodzi się z koncepcji etologicznych i nawiązu-

${ }^{41}$ Z. Szot, dz. cyt., s. 34-37.

${ }^{42}$ Tamże, s. 39.

${ }^{43}$ Z. Szot, Próba prezentacji metody stymulowanych seryjnych powtórzeń ćwiczeń $w$ terapii dzieci autystycznych (SSP), w: Autyzm: kontrowersje i wyzwania, red. W. Dykcik, Poznań 1994, s. $179-180$. 
je do tych założeń psychoanalitycznych, które proces tworzenia się więzi pomiędzy matką i dzieckiem uważają za podstawowy dla dalszego rozwoju osobniczego ${ }^{44}$.

Według N. Tinbergena, jedną z podstawowych przyczyn autyzmu jest brak poczucia bezpieczeństwa dziecka $\mathrm{w}$ jego relacji z matką. Pierwszym naturalnym kontaktem noworodka z matką jest kontakt fizyczny. Stanowi on podłoże dla budowania więzi emocjonalnych i społecznych. Jeżeli związek ten jest zaburzony, dziecko postrzega matkę za osobę słabszą, ponieważ nie daje mu poczucia bezpieczeństwa, i dąży do jej podporządkowania ${ }^{45}$. Stosowanie tej metody ma prowadzić w przypadku dzieci autystycznych do odbudowania zerwanej więzi dziecka z matką.

Decyzję o momencie rozpoczęcia sesji podejmuje matka. Sesje holdingu prowadzone są zazwyczaj w domu, w warunkach dających największy komfort psychiczny. Dziecku należy wyjaśnić, co się będzie z nim robić np.: „będę cię tak długo trzymać, aż nie będziesz wesoły"46. W sesji oprócz matki powinien uczestniczyć ojciec, mogą być również obecni inni członkowie rodziny. Jednakże podczas sesji nie wolno się zmieniać rolami - kiedy matka trzyma dziecko, ojciec pomaga jej tylko wtedy, gdy ona nie może sobie poradzić fizycznie. Rola terapeuty polega na wyjaśnieniu przebiegu sesji terapeutycznej. Interpretuje zachowania i sygnały przekazywane przez dziecko, a następnie przekazuje matce. W czasie seansu terapeutycznego jest on przede wszystkim wnikliwym obserwatorem, natomiast po sesji omawia jej przebieg, wyjaśnia sytuacje, które mogą być niezrozumiałe dla matki.

Marta Welch wyróżniła trzy fazy w trakcie sesji: konfrontacja, odrzucenie, rozwiązanie ${ }^{47}$. Faza odrzucenia jest najbardziej dramatyczną. Dziecko za wszelką cenę próbuje się uwolnić. Podczas trzymania dziecka może ono krzyczeć, płakać, wyrywać się, prężyć, kopać, drapać lub bić matkę, a ona odpowiada na to swoją postawą pełną miłości ${ }^{48}$. W celu zdynamizowania sesji matka powinna wzmagać opór dziecka poprzez pieszczoty, głaskanie, czułe słowa, aż do momentu uzyskania przez dziecko pełnego odprężenia. Ważne jest upewnienie się matki, czy dziecko jest na pewno odprężone. W tym celu należy wsłuchać się w rytm oddechu dziecka, sprawdzić napięcie mięśni (np. dużego palca u nogi). Wiele dzieci autystycznych pozoruje odprężenie i uspokojenie po to, by przerwać kontakt ${ }^{49}$.

Kolejny etap sesji to nawiązanie $\mathrm{z}$ dzieckiem kontaktu rzeczowo-emocjonalnego. Matka nawiązuje $\mathrm{z}$ dzieckiem rozmowę odpowiednią do poziomu jego wieku, prowokuje je do odpowiedzi na pytania. Ta faza powinna trwać najdłużej.

${ }^{44}$ H. Jaklewicz, Autyzm wczesnodziecięcy: diagnoza, przebieg leczenie, Gdańsk 1993, s. 75.

${ }^{45}$ H. Jaklewicz, J. Trzaska, Holding Therapy. Leczenie metodq wymuszonego kontaktu, Psychoterapia 1983, $\operatorname{nr} 3$ (62), s. 89.

${ }^{46}$ Tamże, s. 90-91.

${ }^{47}$ L. Bobrowicz-Lewartowska, dz. cyt., s. 95.

${ }^{48}$ J. Kruk-Lasocka, dz. cyt., s. 83.

${ }^{49}$ H. Jaklewicz, J. Trzaska, dz. cyt., s. 91. 
Warunkiem skuteczności terapii jest niedopuszczenie do przerwania kontaktu w czasie sesji, doprowadzenie dziecka do pełnego odprężenia w czasie każdego seansu. Konieczne jest również prowadzenie co najmniej jednej sesji dziennie ${ }^{50}$.

Terapia holding budzi zdecydowany sprzeciw zwolenników terapii niedyrektywnych, ponieważ uważają oni, że narzucanie czegokolwiek dziecku, a tym bardziej zmuszanie go siłą do kontaktu, jest niedopuszczalne. Pomimo iż metoda ta przez wielu specjalistów jest krytykowana, nie można zaprzeczyć, że posiada ona liczne grono zwolenników wśród rodziców dzieci autystycznych.

Niewątpliwie oba podejścia - niedyrektywne i dyrektywne - mają swoje zalety, jak i obu można również postawić zarzuty. Mimo to każde z podejść niesie ze sobą wartości terapeutyczne.

\section{Zakończenie}

Do dnia dzisiejszego podejmowanych jest wiele badań w celu rozwiązania zagadki określonej mianem „deszczowych dzieci”. Badania te prowadzone są przez przedstawicieli różnych dyscyplin naukowych i różnych szkół psychologicznych. Odnalezienie odpowiedzi na wszystkie pytania stawiane przez naukowców odnośnie autyzmu umożliwiłoby opracowanie skutecznej metody terapii. W dalszym ciagu metody terapeutyczne reprezentują dwa kierunki. Pierwszy kierunek to metody niedyrektywne, w których terapeuta powstrzymuje się od wpływania na poczynania pacjenta. Drugi opisywany kierunek to metody dyrektywne, w których terapeuta kieruje pacjentem w celu wywołania w nim zgodnych z założeniami zmian.

W dyskusjach nad terapią małych dzieci przewija się spór o sens stosowania metod dyrektywnych i niedyrektywnych. Zdaniem Ewy Pisuli, wprowadzenie takiego dychotomicznego podziału i opowiadanie się po jednej ze stron sporu jest całkowicie chybione. Znacznie bardziej owocne okazuje się bowiem łączenie elementów różnych koncepcji i metod, niż uporczywe trwanie przy jednej z opcji.

W Gdańsku w 1997 roku na konferencji naukowej podczas sesji panelowej podjęto dyskusje na temat: Czy można i należy łaczyć różne terapie w pracy $z$ dziećmi autystycznymi?. Wyraźnie zarysowały się wówczas dwa stanowiska.

1. Eklektyczne, dopuszczające łączenie różnych podejść i technik terapeutycznych, jeżeli spełnione są następujące warunki:

- Całościowa ocena, uwzględniająca mocne i słabe strony dziecka z autyzmem, stanowi punkt wyjścia dla terapii.

- Stosowane metody są zaproponowane wcześniej. Dopuszczalne jest modyfikowanie strategii terapeutycznej.

- Stosowane metody muszą być ze sobą spójne. Nie można łączyć ze sobą metod dyrektywnych i niedyrektywnych.

${ }^{50}$ Tenże, dz. cyt., s. 79. 
2) Stanowisko psychologów posługujących się w swojej pracy technikami behawioralnymi, sprzeciwiających się stosowaniu w pracy z dziećmi autystycznymi innych technik poza analizą behawioralną.

Jak można zauważyć, istnieje wiele poglądów na temat łączenia różnych podejść i technik terapeutycznych.

Niniejszy artykuł oparty został przede wszystkim na literaturze, która porusza w swej treści zagadnienie autyzmu. Przedstawione zostały dwa główne podejścia terapeutyczne: niedyrektywne i dyrektywne, jak i rodzaje terapii stosowane w pracy z osobami autystycznymi. Oba podejścia w oddziaływaniach wychowawczych godne są polecania i trudno byłoby przesądzić o wyższości jednego z nich nad drugim. Natomiast pełna ocena skuteczności obu kierunków i metod terapii wykraczałaby poza ramy tego artykułu.

Niestety, nie istnieje aktualnie żadna metoda, która byłaby skuteczna we wszystkich przypadkach autyzmu, wiąże się to prawdopodobnie z ogromnym zróżnicowaniem tego zaburzenia. Mimo to należy wciąż próbować ją odnaleźć. Cierpliwość i miłość są sprzymierzeńcami w drodze do celu.

\section{The Selected Methods of a Theraphy of People Afflicted with Autism in the Light of Literature (Summary)}

This article presents methods of theraphy used in a treatment of persons afflicted with autism. At the beginning the author depicts issues pertaining theraphy of autism. The author showed what the programme for children with autism should be and when and in what conditions its realization is recommended. Next, she presents types of theraphy applied at work with autistic persons and characteristic features of the particular methods. Two main therapeutic approaches are described non-directive - the therapist doesn't have any influence on his/her patient's activities and directive - the therapist leads the patient towards creating in him/her changes which are conformable to the assumptions. 